\title{
Subtidal Microphytobenthos: A Secret Garden Stimulated by the Engineer Species Crepidula fornicata
}

\begin{abstract}
Thibault Androuin ${ }^{1 *}$, Lubos Polerecky2, Priscilla Decottignies ${ }^{3}$, Stanislas F. Dubois ${ }^{1}$, Christine Dupuy ${ }^{4}$, Cédric Hubas ${ }^{5}$, Bruno Jesus ${ }^{3}$, Erwan Le Gall ${ }^{6}$, Martin P. Marzloff' and Antoine Carlier ${ }^{1}$
\end{abstract}

${ }^{1}$ DYNECO-LEBCO, IFREMER, Plouzané, France, ${ }^{2}$ Geochemistry, Department of Earth Sciences, Utrecht University, Utrecht, Netherlands, ${ }^{3}$ EA 2160, Laboratory Mer Molécules Santé, University of Nantes, Nantes, France, ${ }^{4}$ UMR 7266 CNRS, Littoral, Environnement et Sociétés (LIENSS), University of La Rochelle, La Rochelle, France, ${ }^{5}$ Muséum National d'Histoire Naturelle, UMR BOREA 7208 MNHN-Sorbonne Université-CNRS-UCN-UA-IRD, Concarneau, France, ${ }^{6}$ DYNECO-PELAGOS,

IFREMER, Plouzané, France

The slipper limpet Crepidula fornicata is an emblematic invasive species along the northeast Atlantic coast. This gregarious gastropod lives in stacks of several individuals and forms extended beds in shallow subtidal areas. The effects of this engineer species on the colonized habitat can be physical (e.g., presence of hard-shell substrates with uneven topography) or biological (e.g., nutrient enrichment by direct excretion or via biodeposition). We hypothesized that through biological activity, nutrient fluxes at the sediment-water interface are enhanced, leading to stimulated primary productivity by microphytobenthos (MPB) associated with Crepidula beds. To test this fertilization hypothesis, we conducted a 10-day mesocosm experiment using C. fornicata (live and dead) placed on top of sieved and homogenized sediment collected in situ. We used hyperspectral imaging to non-invasively map the development of MPB biomass, and to assess the potential influence of $C$. fornicata and its spatial extent. Our results showed that live $C$. fornicata significantly promote MPB growth through both physical and biological effects, with the biological effect dominating over the pure physical one. The highest stimulation was observed on the shells, suggesting that dissolved metabolic products excreted by $C$. fornicata were likely the main factor stimulating MPB growth in our short-term experiment. Our findings provide first direct evidence that stimulation of MPB growth by the biological activity of larger benthic epifauna occurs not only in intertidal but also in shallow subtidal habitats. More research is needed to assess the contribution of this fertilization effect to the trophic functioning of subtidal benthic systems.

Keywords: Crepidula fornicata, engineer species, subtidal microphytobenthos, fertilization, hyperspectral imaging

\section{INTRODUCTION}

Microphytobenthos (MPB) refers to a complex assemblage of benthic unicellular eukaryotic algae (mainly diatoms) and cyanobacteria living at the sediment-water interface (MacIntyre et al., 1996). MPB is a major component of benthic biofilms, embedded with heterotrophic prokaryotes in a exopolysaccharides matrix (Underwood and Paterson, 2003). It plays a significant role in coastal 
ecosystems through its contribution to primary production (MacIntyre et al., 1996), food web functioning (Riera and Richard, 1996) and sediment stability (Underwood and Paterson, 2003). While intertidal MPB is fairly well-studied (Underwood, 2005; Cartaxana et al., 2011; Juneau et al., 2015; Marques da Silva et al., 2017), its subtidal counterpart has received relatively little attention. However, recent evidence suggests that MPB significantly contributes to shallow areas in terms of biomass (Chatterjee et al., 2013; Hernández Fariñas et al., 2017), primary productivity (Ní Longphuirt et al., 2007) and ultimately food webs (Rigolet et al., 2014).

Microphytobenthos space-time dynamics is affected by a number of abiotic (e.g., light, temperature, nutrient availability, hydrodynamic conditions, and sediment grain size) and biotic (e.g., grazing and competition) factors and their interactions (Seuront and Spilmont, 2002; Azovsky et al., 2004; Jesus et al., 2005). Among these factors, fertilization through the activity of benthic macrofauna is emerging as an important mechanism in benthic ecology (Chennu et al., 2015; Engel et al., 2017; Echappé et al., 2018). Fertilization, which refers to the ability of a species to directly or indirectly promote primary production, can be induced by several processes that affect nutrient availability at the sediment-water interface, e.g., by direct excretion of dissolved nutrients such as ammonia (Prins et al., 1997; Martin et al., 2006; van Broekhoven et al., 2015) or by enhancing organic matter mineralization through biodeposition (e.g., by suspension-feeders) or bioturbation (Kristensen, 2000; Mermillod-Blondin and Rosenberg, 2006). Quantifying the net effect of benthic macrofauna is, however, not straightforward, as it can control the MPB biomass both positively by fertilization and negatively by grazing (Asmus and Asmus, 1991; Porter et al., 2004, 2013). Recent studies demonstrated that MPB productivity in intertidal sediments can be stimulated by different types of engineering macrofauna such as lugworms, oysters and mussels (Chennu et al., 2015; Engel et al., 2017; Echappé et al., 2018). In this study, we aim to explore this phenomenon in subtidal sediments, using the Atlantic slipper limpet Crepidula fornicata as a model of engineering organism in these habitats.

Crepidula fornicata is a gregarious invasive species that spreads along most of the European coasts and is now well established in many shallow embayments (Blanchard, 2009). It is a suspension-feeder that forms very dense beds on the seafloor, with fresh biomass reaching up to $10 \mathrm{~kg} \mathrm{~m}^{-2}$ (Blanchard, 2009). At high densities, this habitat-forming species builds complex 3D benthic habitats (Woods, 1989), and hence constitutes an interesting biological model to assess the effects of ecosystem engineering species on a colonized system (Jones et al., 2010). C. fornicata modifies its surrounding environment in two different ways, which we hereafter refer to as the physical and biological effects. First, their calcareous shells increase heterogeneity and topographic complexity of soft sediment bottoms (Gutiérrez et al., 2003), which enhances the local species diversity (Barnes et al., 1973; de Montaudouin and Sauriau, 1999; de Montaudouin et al., 2017) and modifies hydrodynamic conditions near the sediment-water interface (Moulin et al., 2007). Second, the filter-feeding activity of C. fornicata facilitates benthic-pelagic coupling (Chauvaud et al., 2000), and increases organic enrichment of the sediment through excretion of large amounts of particulate biodeposits (Ehrhold et al., 1998). Additionally, excretion of dissolved metabolic products, such as ammonia, can substantially enhance nutrient's availability in dense Crepidula beds (Martin et al., 2006). In most colonized areas, C. fornicata is a key species of the ecosystem functioning (Chauvaud et al., 2000; Martin et al., 2006).

To assess the potential of $C$. fornicata for fertilization of subtidal MPB, we conducted a short-term (10 days) experiment where we monitored MPB biomass in sediment mesocosms amended with simplified Crepidula beds. We used hyper-spectral imaging to non-invasively monitor MPB biomass and thus infer its growth. To disentangle the role of the physical and biological effects of $C$. fornicata, we compared the MPB growth on bare sediments with that on beds with either dead or live C. fornicata. Moreover, to gain insights into the spatial extent of the biological effect, we compared the growth within and outside of Crepidula beds and on shells, both for dead and live conditions. Additionally, to assess the effects of $C$. fornicata in a larger context, we also quantified concentrations of other key components of biofilms linked with MPB development, including proteins and carbohydrates (used as a proxy for exopolysaccharides) and heterotrophic prokaryotes (used as a proxy for remineralization potential).

\section{MATERIALS AND METHODS}

\section{Experimental Setup}

Sediment and stacks of $C$. fornicata were collected from a dense Crepidula bed (biomass $\sim 6 \mathrm{~kg}$ of fresh weight $\mathrm{m}^{-2}$ ) at $10 \mathrm{~m}$ depth in the bay of Brest $\left(48^{\circ} 23.36068^{\prime} \mathrm{N}, 04^{\circ} 23.86901^{\prime} \mathrm{W}\right)$ on March 1st 2017 (winter season) using a surface grab $\left(0.1 \mathrm{~m}^{2}\right)$. One day after collection, $C$. fornicata stacks were cleaned of their epibionts and the empty shell at the base was removed as it often contains endobiont fauna. Half of the stacks were kept alive while the other half were unstacked, cleared of C. fornicata flesh and reassembled to stacks resembling the original ones using a noninvasive glue (coral glue, PREIS AQUARISTIK ${ }^{\circledR}$ ). Subsequently, both the dead and live stacks were kept for one week in nets in a natural seawater pond to allow filter-feeding of live C. fornicata and partial recovery of MPB biofilms on the shells. No feeding was allowed during the experiment, so excretion of pseudofeces that occurred just after the installation of $C$. fornicata individuals onto the sediment resulted from their feeding activity in the pond.

The freshly collected sediment was first sieved through a $500 \mu \mathrm{m}$ mesh to remove macrofauna that could potentially influence the experiment through their bioturbation and grazing, and then homogenized in a single large tank. After one night, the supernatant was discarded and 12 mesocosms $(60 \mathrm{~L}$ glass aquaria, bottom area of $40 \mathrm{~cm} \times 40 \mathrm{~cm}$ ) were filled evenly with a $5 \mathrm{~cm}$ thick layer (after stabilization) of the slurry. After $24 \mathrm{~h}$ of decantation, each mesocosm was connected to a flowthrough system and let stabilize for 7 days. During this time, the overlying seawater (water column height of $40 \mathrm{~cm}$ ) was replaced at a rate of $15 \mathrm{~L} \mathrm{~min}^{-1}$. The seawater was filtered (5 $\mu \mathrm{m}$ mesh) and supplied from three dark $24 \mathrm{~m}^{3}$ tanks to 
prevent allochthonous primary production from entering the mesocosms. Illumination was supplied in a $12 \mathrm{~h}: 12 \mathrm{~h}$ light:dark cycle using four light emitting diodes (LEDs) with different emission wavelengths (Supplementary Figure 1). Light intensity (PAR) at the sediment surface was $4 \mu \mathrm{mol} \mathrm{m} \mathrm{m}^{-2} \mathrm{~s}^{-1}$, which simulated in situ light conditions in the bay of Brest at $11 \mathrm{~m}$ water depth during winter (Chatterjee et al., 2013). Temperature remained constant at $11.3 \pm 0.4^{\circ} \mathrm{C}$ during the whole experiment.

After the sediment stabilization phase, mesocosms were divided into three treatments and incubated for 10 more days under the same conditions (illumination, temperature, and water flow) as during the stabilization phase. The treatments, each performed in three replicate mesocosms, included a control treatment without $C$. fornicata, a treatment with reconstructed dead shell stacks, and a treatment with live stacks of $C$. fornicata (Figure 1A). For the dead and live treatments, nine stacks of equal initial fresh biomass (4-5 individuals per stack, total biomass $220 \mathrm{~g}$, density $12 \mathrm{~kg} \mathrm{~m}^{-2}$ ) were placed on top of the sediment within a $15 \mathrm{~cm}$ diameter circle in the center of the mesocosms to mimic realistic biomass observed in the field in the bay of Brest (Guérin, 2004).

\section{Hyper-Spectral Imaging of MPB Biomass}

Although extraction-based pigment analysis is a common way to directly quantify the biomass of microscopic primary producers (Wright et al., 1991), its invasive nature does not allow monitoring the biomass of a MPB biofilm in the same location through time. Remote sensing methods are a good alternative to quantify MPB pigments without interfering with the biofilm structure (Paterson et al., 1998; Forster and Jesus, 2006). Among them, hyper-spectral imaging, which is based on capturing backscattered light with high spatial and spectral resolution, has been shown to provide accurate estimates of primary producers' biomass (Carrère et al., 2004; Combe et al., 2005; Barillé et al., 2007; Jesus et al., 2008, 2014; Chennu et al., 2013). Although often used air-borne or space-borne to study MPB distribution at large spatial scales (Méléder et al., 2003; Echappé et al., 2018), this approach can also be used at smaller scales, ranging from single cells to microbial communities such as mats and biofilms (Barranguet et al., 2004; Polerecky et al., 2009a; Perkins et al., 2016). Critically, the non-destructive nature of hyper-spectral imaging allows monitoring of temporal variations in pigment content in the same region of interest, thus allowing inference to the MPB growth (Polerecky et al., 2009b; Chennu et al., 2013).

Hyperspectral imaging of the mesocosms was done immediately after introducing the Crepidula stacks and after $4,5,6,8,9$, and 10 days (Figure 1A). Images were acquired in the VIS-NIR spectral range (400-1000 $\mathrm{nm}$; spectral resolution $1.3 \mathrm{~nm}$ ) using a Pika XC2 imager (RESONON Inc. ${ }^{\circledR}$ ). The imager was mounted on a translation stage (Figure 1B) and controlled using the SPECTRONON software (RESONON Inc. $\left.{ }^{\circledR}\right)$. The entire imaging system was mounted on rollers to allow movement from one mesocosm to another. Imaging was done by scanning the imager at $2.4 \mathrm{~mm} \mathrm{~s}^{-1}$ at $90 \mathrm{~cm}$ from the sediment water interface (SWI) at a nadir position, resulting in a spatial resolution of $250 \mu \mathrm{m}$. Before each scan the water level was carefully lowered down to $10 \mathrm{~cm}$ above SWI to minimize light absorption and scattering in the water column. During scanning, which lasted about 12 min per scan, the imaged area was illuminated with eight halogen lamps (downwelling light intensity at SWI of $40 \mu \mathrm{mol} \mathrm{m} \mathrm{m}^{-2} \mathrm{~s}^{-1}$ ). To enable quantification of spectral reflectance corrected for light absorption in the overlying seawater, a white spectral reference plate was placed on the sediment surface and included in each scan (Polerecky et al., 2009a; Chennu et al., 2013). Because subtidal MPB vertically migrates in the sediment following a diurnal cycle (Ní Longphuirt et al., 2006), affecting spectral reflectance of sediments (Chennu et al., 2013), all mesocosms were scanned within $2 \mathrm{~h}$ at the middle of the day.

\section{Hyper-Spectral Image Processing}

Hyper-spectral image processing employed linear spectral unmixing to extract a proxy for MPB biomass in the studied biofilms from the measured reflectance spectra. Similar approach was successfully used to study the dynamics of MPB populations growing on artificial substrates (Polerecky et al., 2009b). First, the spectral reflectance, $R$, was calculated by normalizing the spectrum of back-scattered light measured in a given pixel with the mean spectrum co-registered in the same scan from the spectral reference plate. The reflectance was then logtransformed to account for the exponentially decreasing light in MPB biofilms due to strong absorption and scattering (Chennu et al., 2013). Finally, the end-member spectra were defined as (1) the spectrum of the MPB-free substrate (both MPBfree sediment and shells had similar reflectance spectra), (2) a wavelength-independent offset describing the general "darkness" of the MPB-covered substrate, and (3) a spectrum containing features typical for MPB pigments including the absorption maxima due to chlorophyll $a$ (Supplementary Figure 2). The 3rd end-member spectrum was determined by subtracting the $\log (R)$ spectra acquired from an MPB-covered and MPB-free substrate, and subsequently removing a constant off-set so that the result became zero at the wavelength of $730 \mathrm{~nm}$. A detailed analysis revealed that all $\log (R)$ spectra could be satisfactorily decomposed into a linear combination of these three end-member spectra, suggesting that there was no significant change in the phototrophic community composition during the experiment. Therefore, the magnitude of the 3rd end-member spectrum was assumed to represent the MPB biomass in the studied biofilms. Since no calibration was performed, the biomass is presented in relative units.

The linear spectral unmixing was performed pixel-by-pixel using the Look@MOSI program (Polerecky et al., 2009a ${ }^{1}$ ), and the resulting images were subsequently processed in Matlab. Specifically, signals representing the MPB biomass were averaged over three regions of interest (ROIs): (1) inner bed sediment, corresponding to the sediment in-between stacks inside the Crepidula beds, (2) outer bed sediment, corresponding to the sediment outside but close to the Crepidula beds, and (3) shells, corresponding to the C. fornicata shells (Figure 1C). A $15 \mathrm{~cm}$ diameter circle in the center of the control mesocosms was used as the reference ROI for the inner bed sediment. ROIs were drawn

${ }^{1}$ http://www.microsen-wiki.net 


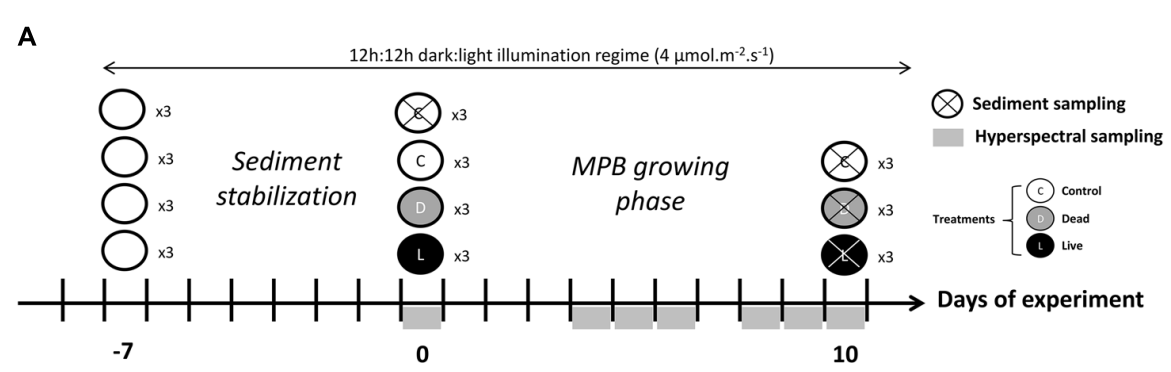

B

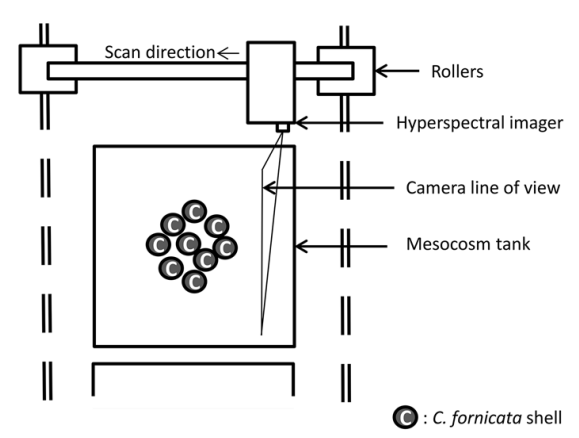

C

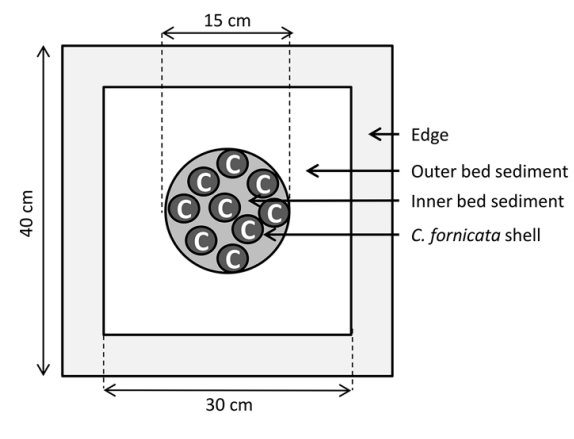

FIGURE 1 | Timeline of the experimental protocol and sampling design (A), top-view schematic of the hyper-spectral imaging system (B), and regions of interest within each mesocosm tank (C).

manually based on the true-color images of the scene constructed from the bands acquired at wavelengths $672 \mathrm{~nm}$ (red), $550 \mathrm{~nm}$ (green), and $490 \mathrm{~nm}$ (blue).

\section{Sediment Sampling and Analysis}

Analysis of the concentrations of total carbohydrates, proteins, and abundances of heterotrophic prokaryotes in the sediment was done on samples collected at the beginning and at the end of the incubation experiment (Figure 1A). This choice of timepoints was restricted by the fact that sampling required for these analyses is destructive. For this purpose, the overlying water was slowly removed to avoid sediment resuspension, and $4 \mathrm{~cm}^{2}$ cores were gently pressed into the sediment at random locations, avoiding areas close to the edge of the mesocosms (Figure 1C). The top $\mathrm{cm}$ of these sediment cores was then sampled using a syringe, homogenized, and divided into three Eppendorf tubes for later analyses. Four cores were sampled in three control mesocosms at the beginning and three control mesocosms at the end of the experiment, whereas eight cores were sampled at the end of the experiment in the dead and live treatments to allow comparison between the outer and inner bed sediment (Figure 1C).

Total carbohydrates concentrations were measured with the colorimetric method (Taylor and Paterson, 1998). Specifically, $200 \mu \mathrm{L}$ of the sediment sample was added to $200 \mu \mathrm{L}$ of $5 \%$ phenol and $1 \mathrm{~mL}$ of sulphuric acid. After incubation at $30^{\circ} \mathrm{C}$ for $35 \mathrm{~min}$, the absorbance of the supernatant was measured at $488 \mathrm{~nm}$. Calibration curves were prepared using glucose.

Total protein concentrations were determined using the modified Lowry method (Frolund et al., 1996). Specifically,
$250 \mu \mathrm{L}$ of the sediment sample was added to $250 \mu \mathrm{L}$ of $2 \%$ SDS (Sodium Dodecyl Sulfate) and $700 \mu \mathrm{L}$ of a mix of chemicals as described by Frolund et al. (1996), and incubated for $15 \mathrm{~min}$ at $30^{\circ} \mathrm{C}$. Subsequently, $100 \mu \mathrm{L}$ of Folin reagent (diluted 5:6 with distilled water) was added to this mixture and incubated for $45 \mathrm{~min}$ at $30^{\circ} \mathrm{C}$. Absorbance of the supernatant was measured at $780 \mathrm{~nm}$. Calibration curves were prepared using bovine serum albumine (BSA).

Abundance of heterotrophic prokaryotes was measured by flow cytometry. Specifically, $1.5 \mathrm{ml}$ of sediment was fixed in $4 \mathrm{ml}$ of filtered $(0.2 \mu \mathrm{m})$ formaldehyde solution ( $2 \%$ final concentration) and stored at $-80^{\circ} \mathrm{C}$. Cells were separated from the sediment and homogenized according to the protocol described by Lavergne et al. (2014). Briefly, $1 \mathrm{~mL}$ of sediment was first diluted sequentially to $1 / 2000$ with $0.01 \mathrm{M}$ sodium pyrophosphate, and then vigorously mixed using a vortex. Samples were then incubated at $4^{\circ} \mathrm{C}$ for $30 \mathrm{~min}$ before sonication (60 W for $30 \mathrm{~s}$ ). Finally, an aliquot of the sample was stained with SYBR Green 1 (1:10 000) for $15 \mathrm{~min}$ in the dark and analyzed by flow cytometry as previously described (Lavergne et al., 2014). Cells abundances were expressed per volume of wet sediment.

\section{Statistical Analysis}

Since MPB biomass was monitored through time, we performed a repeated-measures ANOVA (RM-ANOVA) with the intrasubject factor "Time" and inter-subject factors "Treatment" and "ROI." Because this test compares mean MPB biomass that increased over the period of 10 days, a significant difference in mean values between given treatments corresponds to a significant difference in growth rate between those treatments. 

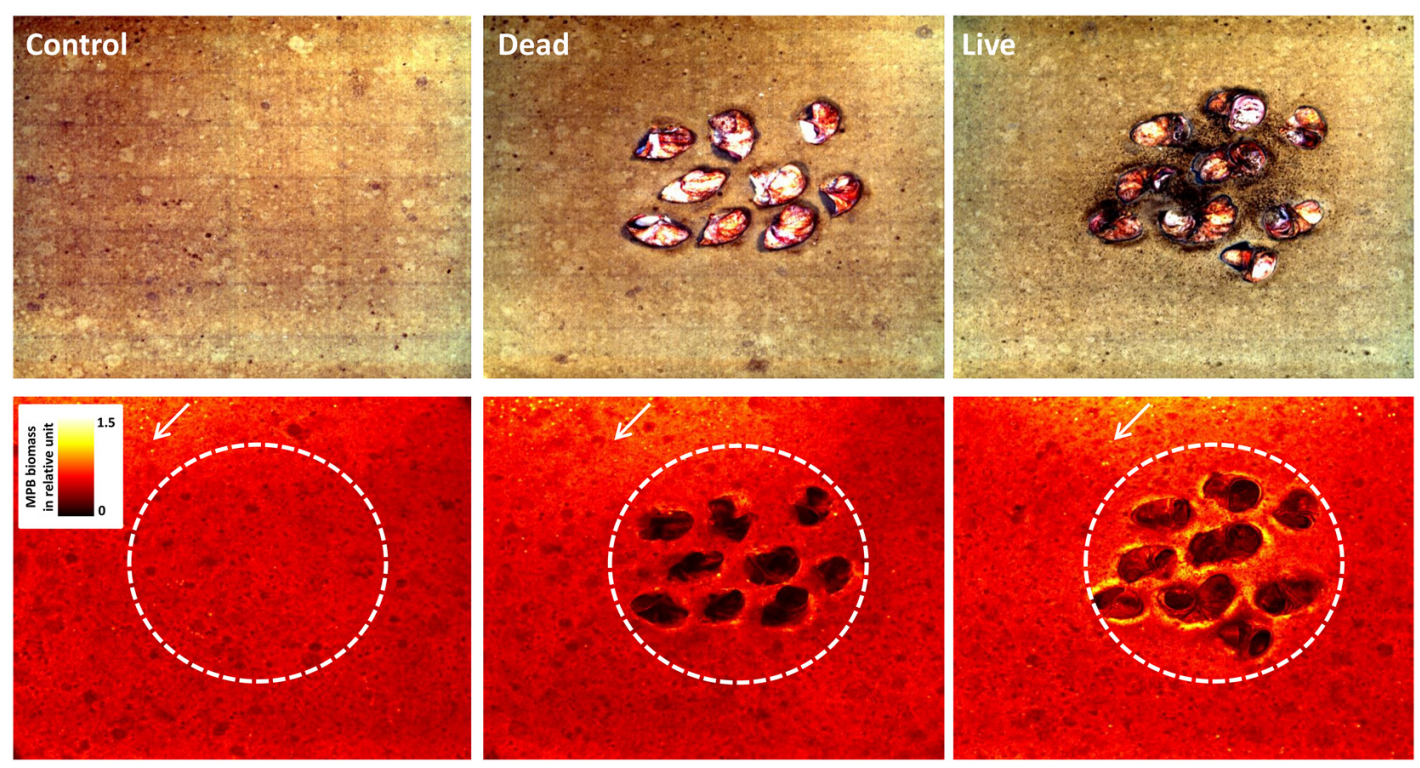

FIGURE 2 | Top view of the sediment surface after 10 days in the experimental mesocosms with the control, dead and live treatments. Shown are examples of true-color images (top row) and the corresponding Microphytobenthos (MPB) biomass maps (in relative units; bottom row). White arrows indicate overlying seawater flow direction. Dashed circles represent the inner bed sediment area.

Two models were used to test for different effects of $C$. fornicata on the MPB development. The first model compared MPB biomass in the inner bed sediment through time as a function of the three treatments (i.e., control, dead, and live), with the aim to quantify the importance of the physical and biological effects at a local scale. The second model compared the three ROIs (i.e., outer, inner, and shells) between the dead and live treatments, with the aim to assess the spatial extent of the biological effect of C. fornicata. For each RM-ANOVA, variance-covariance matrix sphericity was verified using Mauchly test. When significant, $p$-values were re-calculated using the Greenhouse-Geisser correction. When F-tests were significant, post hoc comparisons were calculated using contrasts for factor interactions and using Bonferroni-corrected $p$-values. Concentrations of carbohydrates, proteins and heterotrophic prokaryotes were compared between time, treatments and ROIs. Differences were assessed using the Kruskal-Wallis test based on ranks, followed by a post hoc analysis using Bonferroni-corrected Mann-Whitney tests. This was done (instead of RM-ANOVA) because we used the first time measurement as a control for all treatments (bare sediment, dead, and live), so all treatments have the same departure condition. Therefore there is no need to take into account the intra-subject factor "Time." Statistical analyses were performed in R (version 3.3.0; R Core Team, 2012) using packages "car," "plyr," "phia," and "ggplot."

\section{RESULTS}

After 10 days of incubation, the effect of C. fornicata on the MPB distribution in the mesocosms was clearly visible (Figure 2).

Patches with highest MPB biomass occurred within the inner bed sediment of live treatments, whereas lowest MPB biomass was found on the shells from the dead treatment. For all treatments, MPB biomass decreased with the distance from the seawater inlets (located at the top of the images in Figure 2), indicating that more turbulent hydrodynamic conditions in the water-column also had a positive effect on MPB growth.

\section{Physical vs. Biological Effect in the Inner Bed Sediment}

For all treatments, MPB biomass in the inner bed sediment increased approximately linearly over the course of the experiment (Figure 3). The mean MPB biomass was significantly different between treatments $(p<0.0001$, Table 1). Post hoc multiple comparisons revealed that the MPB biomass was significantly higher (by $\sim 7 \%$ ) in the dead treatment than in the control $(p=0.03)$, was significantly higher (by $\sim 12 \%$ ) in the live than in the dead treatment $(p<0.01)$, and was significantly higher (by $\sim 19 \%$ ) in the live than in the control treatment $(p<0.0001)$. These results imply that both physical and biological effects of $C$. fornicata on MPB growth occurred in our experiment and that the biological effect was stronger than the physical effect. Moreover, these effects appear to be additive rather than synergic, i.e., the cumulate effect is the sum of the physical and biological effects $(7 \%+12 \%=19 \%)$ with no apparent interaction between the two.

\section{Spatial Extent of the Biological Effect}

The high spectral resolution of the hyper-spectral imaging-based pigment analysis was instrumental in discriminating between pseudofeces and MPB biomass. While both categories appeared dark-brown in the true-color images (Figures $\mathbf{4 A , B}$ ), the 2nd 


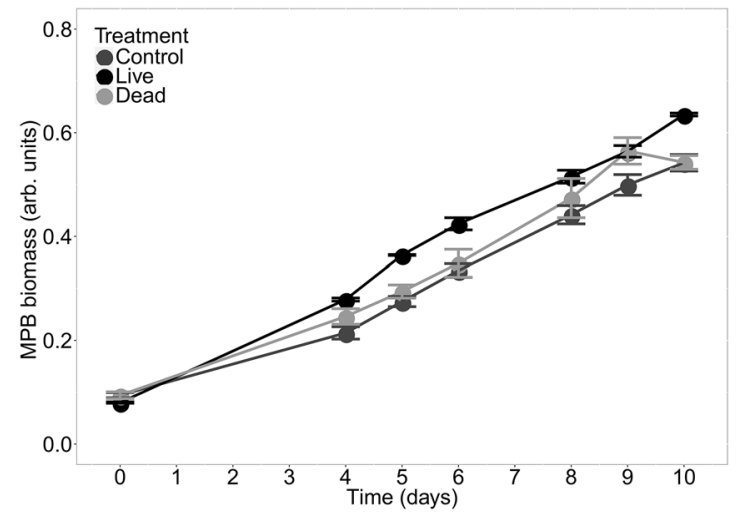

FIGURE 3 | MPB biomass (mean \pm SE, $n=3$ ) as a function of time measured at the surface in the inner bed sediment for the three treatments.

and 3rd end-member spectra identified pseudofeces and MPB, respectively. Images of the magnitude of the 2 nd end-member showed that pseudofeces were distributed on one side of live stacks (e.g., white arrow (1) in Figure 4D), predominantly in the direction of ex-current flow associated with filtration of C. fornicata individuals (which all are oriented in the same way), and that they were clearly absent around the dead Crepidula stacks (Figure 4C). In contrast, MPB biomass was distributed heterogeneously on and around shells, with the highest density close to live shells (e.g., white arrow (2) in Figure 4F, contrast with Figure 4E).

Microphytobenthos biomass displayed contrasted responses in the dead and live treatments among the different ROIs (Figures 5A,B). The model incorporating both effects of treatment and ROI on MPB biomass revealed significant effect of both "Treatment" $(p<0.0001)$ and "ROI" $(p<0.0001)$ factors as well as of the interaction "Treatment:ROI" $(p<0.0001)$ (Figure 5C and Table 2). Post hoc multiple comparisons showed that the MPB biomass was not significantly different on the outer bed sediment between dead and live treatments $(p=0.41)$. However, live treatment showed significantly higher MPB biomass than the dead treatment both for inner bed sediment $(p<0.01)$ and for shells $(p<0.0001)$. Moreover, the

TABLE 1 | Results of the RM-ANOVA applied to assess differences in Microphytobenthos (MPB) biomass between the three treatments in the inner bed sediment.

\begin{tabular}{|c|c|c|c|c|c|}
\hline & & num Df & den Df & approx $F$ & $p$-value \\
\hline \multicolumn{6}{|l|}{ RM-ANOVA } \\
\hline (Intercept) & & 1 & 20 & 104.01 & $3 \times 10^{-9}$ \\
\hline \multirow[t]{2}{*}{ Treatment } & & 2 & 19 & 19.81 & $3 \times 10^{-5}$ \\
\hline & Value & num Df & den Df & approx $F$ & $p$-value \\
\hline \multicolumn{6}{|l|}{ Post hoc test } \\
\hline Control - Dead & -0.023 & 1 & 20 & 5.64 & 0.028 \\
\hline Control - Live & -0.066 & 1 & 20 & 40.5 & $1 \times 10^{-5}$ \\
\hline Dead - Live & -0.042 & 1 & 20 & 11.1 & $7 \times 10^{-3}$ \\
\hline
\end{tabular}

relative difference in MPB biomass between the dead and live treatments was higher on shells (by 50\%) than on the inner bed sediment (by 12\%). Together, these results showed that the enhancement of the MPB growth by the biological activity of $C$. fornicata progressively decreased with the distance from the shells: while the effect was significant both on shells and on the inner bed sediment, with the former more pronounced than the latter, the effect disappeared on the outer bed sediment.

\section{Evolution of Carbohydrates, Proteins and Heterotrophic Prokaryotes}

In contrast to the clear differences between treatments and ROIs observed for the MPB biomass at the sediment surface, no significant differences between the beginning and end of the experiment and among the treatments were found for any of the three additional sediment properties (Figure 6). Carbohydrates concentrations were not significantly different between conditions $(F=4.72, p=0.45)$. The same conclusion was reached for protein content $(F=3.93, p=0.56)$. Heterotrophic prokaryotes abundances showed significant differences among treatments $(F=16.76, p<0.01)$, however, post hoc multiple comparisons failed to find any significant differences.

\section{DISCUSSION}

\section{Effects of Crepidula fornicata on Subtidal Microphytobenthos}

Our results showed that at a local scale (i.e., inner bed sediment), and on a time-scale of days, the engineer species $C$. fornicata stimulated subtidal MPB growth, through both physical and biological effects. Moreover, the biological effect was more important than the pure physical one linked to the presence of shells. This result is consistent with the hypothesis that the biological activity of this species promotes MPB growth via enhanced nutrient supply. Thus, it adds to a growing body of evidences showing that ecosystem engineering species have promoting effects on benthic primary production (Chennu et al., 2015; Engel et al., 2017; Echappé et al., 2018). Our data also showed that the enhancement of MPB growth by the biological activity of $C$. fornicata depends on the distance from the

TABLE 2 | Results of the RM-ANOVA applied to assess differences in MPB biomass between two treatments and three ROls.

\begin{tabular}{|c|c|c|c|c|c|}
\hline & & num Df & den Df & approx $F$ & $p$-value \\
\hline \multicolumn{6}{|l|}{ RM-ANOVA } \\
\hline (Intercept) & & 1 & 20 & 102.5 & $3 \times 10^{-9}$ \\
\hline Treatment & & 1 & 20 & 18.3 & $4 \times 10^{-4}$ \\
\hline ROI & & 2 & 19 & 51.94 & $8 \times 10^{-10}$ \\
\hline Treatment:ROI & & 2 & 19 & 14.97 & $3 \times 10^{-3}$ \\
\hline Dead - Live & Value & num Df & den Df & approx $F$ & $p$-value \\
\hline \multicolumn{6}{|l|}{ Post hoc test } \\
\hline Outer & -0.01 & 1 & 20 & 0.72 & 0.41 \\
\hline Inner & -0.04 & 1 & 20 & 11.09 & $9 \times 10^{-3}$ \\
\hline Shell & -0.06 & 1 & 20 & 51.66 & $2 \times 10^{-6}$ \\
\hline
\end{tabular}



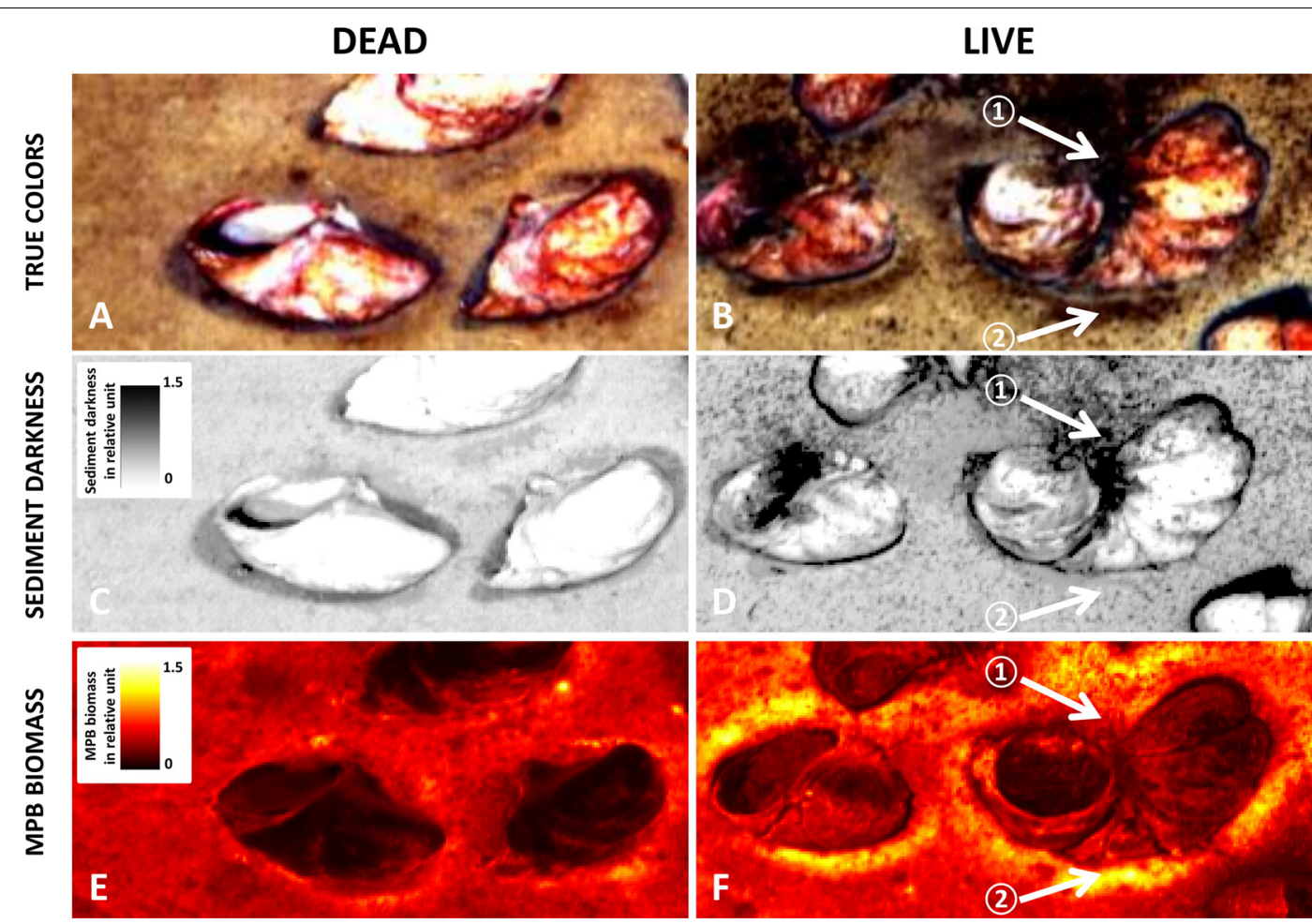

FIGURE 4 | Close-up images of sediment surface within the experimental Crepidula fornicata bed after 10 days. Shown are true color images with enhanced contrast $(\mathbf{A}, \mathbf{B})$ with corresponding sediment darkness maps $(\mathbf{C}, \mathbf{D})$, and MPB biomass maps $(\mathbf{E}, \mathbf{F})$ in live and dead treatments.
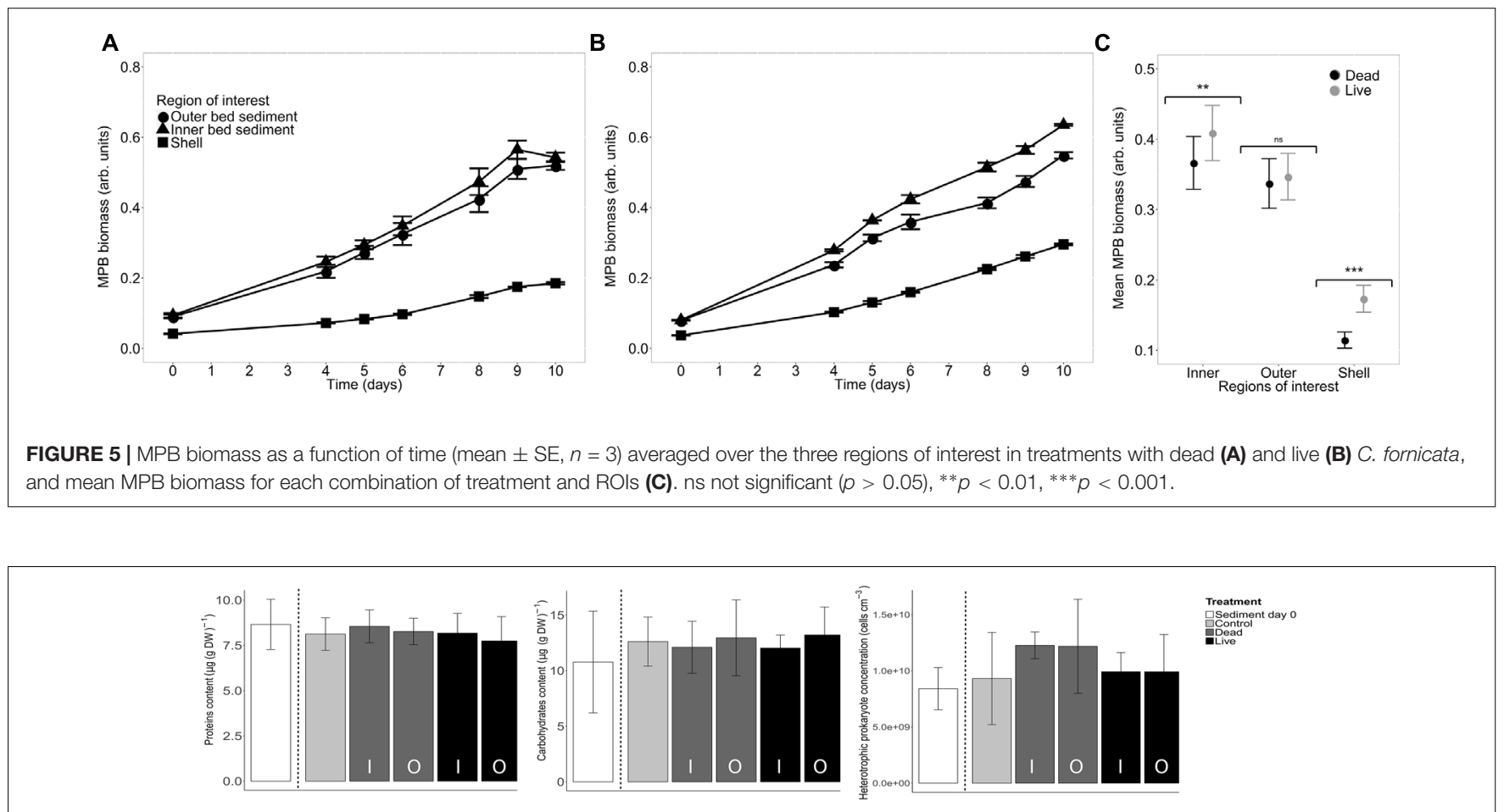

FIGURE 6 | Comparison of concentrations of proteins, carbohydrates and abundance of heterotrophic prokaryotes between treatments. Shown are averages and $\mathrm{SD}$ of four samples collected at days 0 and 10 from the inner $(\mathrm{I})$ and outer $(\mathrm{O})$ bed sediment for the dead and live treatments. 


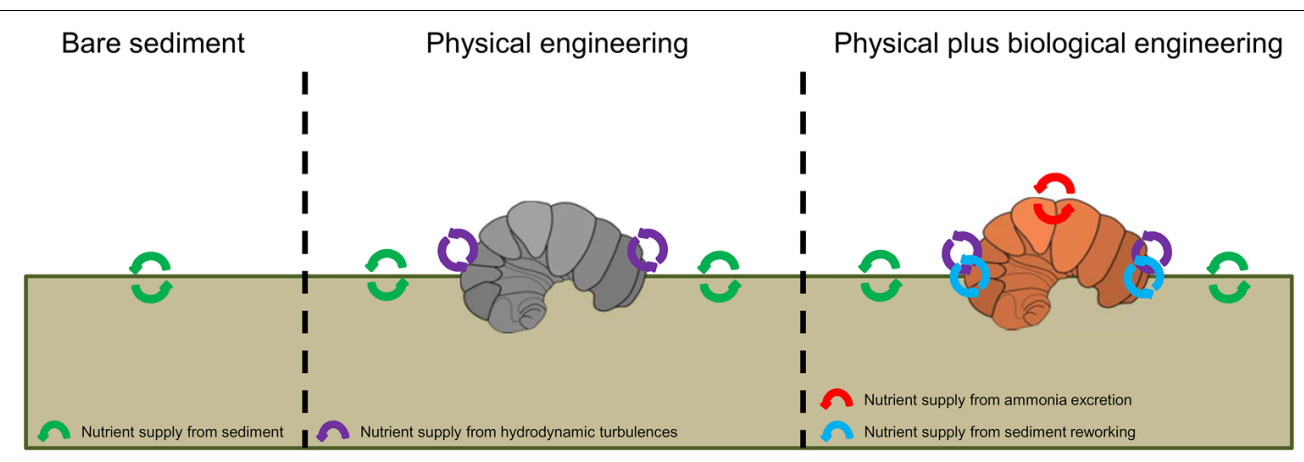

FIGURE 7 | Schematic diagram of the effects of $C$. fornicata on MPB growth, discriminating between the effects of dead (physical engineering) and live (physical plus biological engineering) animals.

individuals; while MPB growth increased on shells and inner bed sediment, no effect was observed outside the C. fornicata bed. This spatial heterogeneity may reflect different processes involved in the enhancement of nutrient supply, as discussed below.

Regarding the physical effect, C. fornicata influences hydrodynamics in the overlying water by increasing rugosity of the benthic boundary layer as shell's density increases (Moulin et al., 2007). The resulting sheltering effect against erosion has been suggested to explain enhanced MPB growth conditions in natural mollusk beds (Engel et al., 2017). Although the hydrodynamics was lower in our experiment than in natural conditions, it is possible that this sheltering effect also played a role in our mesocosms. However, another possible explanation is that, similar to what occurs in permeable sediments with ripples (Precht et al., 2004), nutrient efflux at the sediment-water interface around $C$. fornicata shells was increased by a small but significant advective porewater outflow induced by the complex interactions between the overlying water flow and the seabed micro-topography, ultimately leading to enhanced MPB growth. This explanation is supported by our observation that, in addition to the inner bed sediment, the enhanced MPB biomass growth was also observed close to the water inlets in our mesocosms, where a locally increased advective efflux of porewater nutrients induced by over-pressurization of porewater relative to the overlying water (due to a locally faster flow) is plausible.

Regarding the biological effect, our data suggest that excretion of dissolved metabolic products is likely the main factor promoting MPB growth in Crepidula beds on time-scale of days. Although we have not measured nutrient concentrations directly, this hypothesis is supported by the interpretation of our hyperspectral data. Specifically, if nutrients supporting the growth of MPB on shells were delivered only via transport from the sediment next to the shells, their concentrations at the shell-water interface would be, due to dilution, lower than at the sedimentwater interface. This would imply that, when comparing the life vs. dead treatment, their stimulation of MPB growth on shells should not exceed the stimulation on the sediment. However, the relative difference in MPB growth between our live and dead treatments was larger on shells (50\%) than on the sediment $(12 \%)$. This is only possible if the shells of live C. fornicata individuals acted as an additional nutrient source, even stronger than the sediment around the shells. The most likely mechanism behind such a nutrient source is direct excretion of dissolved metabolic products by $C$. fornicata. However, more experiments involving direct nutrient measurements are necessary to further test this hypothesis. Nutrient supply from mollusk metabolism has been shown to be a significant process in primary production fertilization (Asmus and Asmus, 1991; Gardner et al., 1995; Newell et al., 2005). Our data combined with the observation that C. fornicata catabolism accounts for $85 \%$ of the benthic community excretion in natural Crepidula beds (Martin et al., 2006) suggest that excretion of dissolved metabolic products plays potentially an important role in benthic primary production in these habitats, as previously suggested by Ní Longphuirt et al. (2007).

However, there are additional mechanisms that might enhance nutrient supply in Crepidula beds (Figure 7). First, C. fornicata is a suspension-feeder that significantly contributes to organic enrichment of the sediment through biodeposition (Manac'h, 1995; Ehrhold et al., 1998). Inorganic nitrogen produced by the mineralization of biodeposits can be a significant nutrient source for primary producers (Newell, 2004; van Broekhoven et al., 2015). After C. fornicata produced pseudofeces at the beginning of the incubation phase, a slow but stable remineralization process probably occurred over the course of our experiment. However, the fact that the highest MPB biomass recorded in the vicinity of live shells did not overlap with the area covered by pseudofeces (Figures 4D,F) indicates that pseudofeces were not the main cause of MPB fertilization during our short-term experiment. Because pseudofeces tend to accumulate on the substrate, this process probably plays a significant role in medium-to-long-term stimulation of MPB development in natural Crepidula beds (Laruelle et al., 2009). A second possibility, consistent with the fact that the highest MPB biomass was observed in the close vicinity of the live individuals' shells, is linked to postural changes of C. fornicata (Powell-Jennings and Callaway, 2018). As suggested by Loomis and van Nieuwenhuyze (1985), movements of C. fornicata individuals in direct contact with muddy sediment destabilize the sediment-water interface. This bioturbation can promote MPB growth by increasing nutrient fluxes from underlying pore water. Finally, solubilization 
of mucous is also known to promote MPB growth through the supply of dissolved nutrients, as shown for mollusks (Cognie and Barille, 1999). C. fornicata secretes high amounts of mucous during its filter-feeding activity (Shumway et al., 2014), which can also contribute to promote MPB development.

In our experiment the clear increase in the MPB biomass was not accompanied by the corresponding increase in the other biofilm components measured (i.e., proteins, carbohydrates, and heterotrophic prokaryotes). This was an unexpected result given that previous studies did observe coupling between these parameters and the MPB growth (Orvain et al., 2003; Underwood and Paterson, 2003; Hubas et al., 2010). The absence of changes in these biofilm parameters could indicate that during our experiment, the fertilization impact of $C$. fornicata was restricted to the very surface of the sediment, and that we did not detect these changes due to an insufficient sampling resolution. Indeed, carbohydrates, proteins, and heterotrophic prokaryotes were measured in the top $\mathrm{cm}$, while MPB biomass quantification by the hyper-spectral imaging method is limited to the depth of light penetration (Chennu et al., 2013), which is about $0.3 \mathrm{~mm}$ in marine muddy sediments (Kühl et al., 1994). Thus, even if significant changes in carbohydrates, proteins, and heterotrophic prokaryotes did occur within the MPB biofilms, they were likely minor compared to their standing stocks in the top $\mathrm{cm}$ of the sediment, and thus not detected. Another possibility is that the conditions employed in our experiment were not optimal to maintain a clear link between the MPB biomass and the concentrations of the other parameters. For instance, exopolysaccharides (EPS) produced by MPB (mixture of proteins and carbohydrates) could have been removed by the overlying water through solubilization and/or hydrolysis (Orvain et al., 2003; Underwood and Paterson, 2003). Additionally, their production is driven by photosynthesis and thus strongly depends on irradiance and temperature (Perkins et al., 2001; Smith and Underwood, 2001). The rather low temperature and irradiance, combined with the continuous water flow in the mesocosms, likely limited EPS accumulation, and thus its colonization by heterotrophic prokaryotes, in the MPB biofilms in our experiment.

\section{Limitations}

In our study we did not calibrate our hyper-spectral data against the concentrations of MPB in the sediment, but relied on previous studies that showed that hyper-spectral measurements provide accurate measures of MPB biomass (Carrère et al., 2004; Combe et al., 2005; Barillé et al., 2007; Jesus et al., 2008, 2014; Chennu et al., 2013). Nevertheless, to indicate the range of the actual MPB biomass in our mesocosms, we measured chlorophyll $a$ concentrations by HPLC for a limited number of sediment samples ( $1 \mathrm{~cm}$ deep sediment cores; see Supplementary Information for protocol). For the study site, the in situ chlorophyll $a$ concentrations were $17-24 \mu \mathrm{g}(\mathrm{g} \mathrm{DW})^{-1}(n=2)$, which is similar to the value reported previously for a subtidal muddy sediment in the bay of Brest in winter $\left(18 \mu \mathrm{g}(\mathrm{g} \mathrm{DW})^{-1}\right.$; Riaux-Gobin et al., 1987). With respect to the experiment, chlorophyll $a$ concentrations in the mesocosms increased from 26-29 $\mu \mathrm{g}\left(\mathrm{g} \mathrm{DW}^{-1}(n=4)\right.$ to $60-136 \mu \mathrm{g}\left(\mathrm{g} \mathrm{DW}^{-1}(n=10)\right.$ between days 0 and 10, which is an increase by a factor of 2-5 (3.5 on average). Taking into account the substantially larger sampling depth of this HPLC-based pigment analysis $(1 \mathrm{~cm})$, this increase was consistent with the relative increase in the MPB biomass derived from our hyper-spectral measurements (by a factor of 5-6; Figure 3).

While our experimental design was able to detect significant effects of C. fornicata on the MPB growth rate, its duration was not adequate for quantifying differences in the biotic capacity of the studied system (Orvain et al., 2003). Indeed, at the end of the experiment, although MPB growth appeared to slow down in the dead treatment, MPB was still growing at roughly a constant rate in the live treatment, irrespective of the ROI (Figures 5A,B). The duration of our experiment was designed according to previous experiments investigating similar ecological processes (Orvain et al., 2003; Agogué et al., 2014; Chennu et al., 2015; Jauffrais et al., 2015). Based on these reports we expected the MPB to follow a logistic growth model and reach a plateau within $\sim 10$ days (Orvain et al., 2003; Chennu et al., 2015; Jauffrais et al., 2015). However, the abiotic conditions chosen for our experiment (e.g., winter temperature and low light) were probably too harsh for the MPB to approach the biotic capacity of the substrate in such a short time. We suggest that future experiments studying shortterm effects of altered nutrient supply on MPB growth should employ slightly longer duration of the experimental treatments (e.g., 2-3 weeks) to allow a more complete understanding of the growth dynamics.

\section{CONCLUSION}

Overall, we provided evidence that C. fornicata enhances the growth of microphytobenthic biofilms. Our experiment disentangled two potential effects of this engineer species (physical vs. biological), and revealed that live Crepidula beds supported faster MPB growth than dead ones. Dissolved metabolic products excreted by $C$. fornicata were likely the main factor stimulating MPB growth in our short term experiment. While fertilization of MPB by engineer species such as mussels (Engel et al., 2017), oysters (Echappé et al., 2018) or lugworms (Chennu et al., 2015) has been documented for intertidal sediments, our study is the first to quantify this phenomenon in a subtidal habitat.

Considering the large geographical extent of this invasive species in shallow European waters (Blanchard, 2009), the potential contribution of $C$. fornicata to subtidal benthic primary production and its fate in higher trophic levels need to be further investigated. Despite emerging evidence of its trophic significance (Grall et al., 2006; Evrard et al., 2012; Rigolet et al., 2014), subtidal MPB remains difficult to sample and hence is usually disregarded as a potential source of labile organic matter in benthic food-web studies. The trophic role of subtidal MPB is likely to be significant in C. fornicata habitats, where the biomass of primary consumers (i.e., deposit- and suspension-feeders) is high (de Montaudouin et al., 1999; Ní Longphuirt et al., 2007). Because it has no predators in its introduction area, C. fornicata is considered to be a trophic 
dead-end (Arbach Leloup et al., 2008). Nevertheless, the intense filtering activity and the low assimilation efficiency of this species (Shumway et al., 2014) suggest that C. fornicata may redirect a large amount of energy and material from the water column to the benthic compartment not only through biodeposition (Chauvaud et al., 2000), but also through stimulation of benthic primary production.

Despite invasive species being generally considered as a threat for ecosystems, their engineering effects have the potential to enhance ecosystem functioning and compensate for the loss of native habitats (Ramus et al., 2017; Romić and Nakajima, 2017). In the case of $C$. fornicata, both its physical (e.g., habitatforming heterogeneity and niche provisioning) and biological (e.g., stimulation of MPB growth) engineering effects could offset the negative ecological impacts usually attributed to this species.

\section{AUTHOR CONTRIBUTIONS}

TA, PD, SD, CD, CH, BJ, and AC designed the experiments. TA, PD, SD, ELG, MM, and AC prepared the experiments. TA performed the experiments. TA and CD carried out laboratory analysis. TA, LP, and MM analyzed the data. TA, LP, SD, MM, and AC interpreted the data. TA and LP led the development of the manuscript, with all authors contributing to the writing of the manuscript.

\section{REFERENCES}

Agogué, H., Mallet, C., Orvain, F., De Crignis, M., Mornet, F., and Dupuy, C. (2014). Bacterial dynamics in a microphytobenthic biofilm: a tidal mesocosm approach. J. Sea Res. 92, 36-45. doi: 10.1016/j.seares.2014. 03.003

Arbach Leloup, F., Desroy, N., Le Mao, P., Pauly, D., and Le Pape, O. (2008). Interactions between a natural food web, shellfish farming and exotic species: the case of the Bay of Mont Saint Michel (France). Estuar. Coast. Shelf Sci. 76, 111-120. doi: 10.1016/j.ecss.2007.06.011

Asmus, R. M., and Asmus, H. (1991). Mussel beds: limiting or promoting phytoplankton? J. Exp. Mar. Biol. Ecol. 148, 215-232. doi: 10.1016/00220981(91)90083-9

Azovsky, A. I., Chertoprood, E. S., Saburova, M. A., and Polikarpov, I. G. (2004). Spatio-temporal variability of micro- and meiobenthic communities in a White Sea intertidal sandflat. Estuar. Coast. Shelf Sci. 60, 663-671. doi: 10.1016/j.ecss. 2004.03.005

Barillé, L., Méléder, V., Combe, J.-P., Launeau, P., Rincé, Y., Carrère, V., et al. (2007). Comparative analysis of field and laboratory spectral reflectances of benthic diatoms with a modified Gaussian model approach. J. Exp. Mar. Biol. Ecol. 343, 197-209. doi: 10.1016/j.jembe.2006.11.013

Barnes, R. S. K., Coughlan, J., and Holmes, N. J. (1973). A preliminary survey of macroscopic fauna, with particular reference to Crepidula fornicata. Proc. Malacol. Soc. Lond. 40, 253-275.

Barranguet, C., van Beusekom, S., Veuger, B., Neu, T., Manders, E., Sinke, J., et al. (2004). Studying undisturbed autotrophic biofilms: still a technical challenge. Aquat. Microbial. Ecol. 34, 1-9. doi: 10.3354/ame034001

Blanchard, M. (2009). Recent expansion of the slipper limpet population (Crepidula fornicata) in the Bay of Mont-Saint-Michel (Western Channel, France). Aquat. Living Resour. 22, 11-19. doi: 10.1051/alr/2009004

Carrère, V., Spilmont, N., and Davoult, D. (2004). Comparison of simple techniques for estimating chlorophyll a concentration in the intertidal zone

\section{FUNDING}

This study is part of the TRECH project funded by the Total Foundation for the Biodiversity and the Sea. TA received a Ph.D. grant from IFREMER and Region Bretagne.

\section{ACKNOWLEDGMENTS}

We thank JM. Pédron for providing access to aquaculture facility, C. Cordier and X. Caisey for the technical support during field sampling and experiment, D. Morigeon and F. Quéré for their kind assistance on board of the R/V Albert Lucas, G. Delebecq for providing in situ light spectra, and A. Jones and B. Taormina for helpful discussions. Prokaryotes analyses were performed using the cytometry and imaging platform of the LIENSs laboratory in La Rochelle, and we also thank M. Bréret and L. Beaugeard for the technical assistance. We acknowledge IFREMER, LabexMER and Region Bretagne for co-funding TA's Ph.D. and LP's collaboration visits. We are grateful for the comments and suggestions made by reviewers that improved this manuscript.

\section{SUPPLEMENTARY MATERIAL}

The Supplementary Material for this article can be found online at: https://www.frontiersin.org/articles/10.3389/fmars. 2018.00475/full\#supplementary-material

using high spectral-resolution field-spectrometer data. Mar. Ecol. Progr. Ser. 274, 31-40. doi: 10.3354/meps274031

Cartaxana, P., Ruivo, M., Hubas, C., Davidson, I., Serôdio, J., and Jesus, B. (2011). Physiological versus behavioral photoprotection in intertidal epipelic and epipsammic benthic diatom communities. J. Exp. Mar. Biol. Ecol. 405, 120-127. doi: 10.1016/j.jembe.2011.05.027

Chatterjee, A., Klein, C., Naegelen, A., Claquin, P., Masson, A., Legoff, M., et al. (2013). Comparative dynamics of pelagic and benthic micro-algae in a coastal ecosystem. Estuar. Coast. Shelf Sci. 133, 67-77. doi: 10.1016/j.ecss.2013. 08.015

Chauvaud, L., Jean, F., Ragueneau, O., and Thouzeau, G. (2000). Long-term variation of the bay of Brest ecosystem: benthic-pelagic coupling revisited. Mar. Ecol. Progr. Ser. 200, 35-48. doi: 10.3354/meps200035

Chennu, A., Färber, P., Volkenborn, N., Al-Najjar, M. A. A., Janssen, F., de Beer, D., et al. (2013). Hyperspectral imaging of the microscale distribution and dynamics of microphytobenthos in intertidal sediments. Limnol. Oceanogr. 11, 511-528. doi: 10.4319/lom.2013.11.511

Chennu, A., Volkenborn, N., De Beer, D., Wethey, D. S., Woodin, S. A., and Polerecky, L. (2015). Effects of bioadvection by Arenicola marina on microphytobenthos in permeable sediments. PLoS One 10:e0134236. doi: 10. 1371/journal.pone.0134236

Cognie, B., and Barille, L. (1999). Does bivalve mucus favour the growth of their main food source, microalgae? Oceanol. Acta 22, 441-450. doi: 10.1016/S03991784(00)88727-7

Combe, J., Launeau, P., Carrere, V., Despan, D., Meleder, V., Barille, L., et al. (2005). Mapping microphytobenthos biomass by non-linear inversion of visibleinfrared hyperspectral images. Remote Sens. Environ. 98, 371-387. doi: 10.1016/ j.rse.2005.07.010

de Montaudouin, X., Audemard, C., and Labourg, P.-J. (1999). Does the slipper limpet (Crepidula fornicata, L.) impair oyster growth and zoobenthos biodiversity? A revisited hypothesis. J. Exp. Mar. Biol. Ecol. 235, 105-124. doi: 10.1016/S0022-0981(98)00167-1 
de Montaudouin, X., Blanchet, H., and Hippert, B. (2017). Relationship between the invasive slipper limpet Crepidula fornicata and benthic megafauna structure and diversity, in Arcachon bay. J. Mar. Biol. Assoc. U.K. 1-12. doi: 10.1017/ S0025315417001655

de Montaudouin, X., and Sauriau, P. G. (1999). The proliferating Gastropoda Crepidula fornicata may stimulate macrozoobenthic diversity. J. Mar. Biol. Assoc. U.K. 79, 1069-1077. doi: 10.1017/S0025315499001319

Echappé, C., Gernez, P., Méléder, V., Jesus, B., Cognie, B., Decottignies, P., et al. (2018). Satellite remote sensing reveals a positive impact of living oyster reefs on microalgal biofilm development. Biogeosci. Discuss. 15, 905-918. doi: 10.5194/ bg-2017-326

Ehrhold, A., Blanchard, M., Auffret, J.-P., and Garlan, T. (1998). Conséquences de la prolifération de la crépidule (Crepidula fornicata) sur l'évolution sédimentaire de la baie du Mont-Saint-Michel (Manche, France). Comptes Rendus de l'Académie des Sciences de Paris, Science de la Terre et des Planètes 327, 583-588. doi: 10.1016/S1251-8050(99)80111-6

Engel, F. G., Alegria, J., Andriana, R., Donadi, S., Gusmao, J. B., van Leeuwe, M. A., et al. (2017). Mussel beds are biological power stations on intertidal flats. Estuar. Coast. Shelf Sci. 191, 21-27. doi: 10.1016/j.ecss.2017.04.003

Evrard, V., Huettel, M., Cook, P., Soetaert, K., Heip, C., and Middelburg, J. (2012). Importance of phytodetritus and microphytobenthos for heterotrophs in a shallow subtidal sandy sediment. Mar. Ecol. Progr. Ser. 455, 13-31. doi: 10.3354/ meps09676

Forster, R. M., and Jesus, B. (2006). Field spectroscopy of estuarine intertidal habitats. Int. J. Remote Sens. 27, 3657-3669. doi: 10.1080/01431160500500367

Frolund, B., Palmgren, R., Keiding, K., and Nielsen, P. H. (1996). Exctraction of extracellular polymers from activated sludge using a cation exchange resin. Water Res. 30, 1749-1758. doi: 10.1016/0043-1354(95)00323-1

Gardner, W., Cavaletto, J., Johengen, T., Johnson, J., Heath, R., and Cotner, J. B. (1995). Effects of the zebra mussels, Dreissena polymorpha, on community nitrogen dynamics in Saginaw Bay, Lake Huron. J. Great Lakes Res. 21, 529-544. doi: 10.1016/S0380-1330(95)71064-4

Grall, J., Le Loc'h, F., Guyonnet, B., and Riera, P. (2006). Community structure and food web based on stable isotopes ( $\delta 15 \mathrm{~N}$ and $\delta 13 \mathrm{C}$ ) analysis of a North Eastern Atlantic maerl bed. J. Exp. Mar. Biol. Ecol. 338, 1-15. doi: 10.1016/j.jembe.2006. 06.013

Guérin, L. (2004). La crépidule en rade de Brest: un modèle biologique d'espèce introduite proliférante en réponse aux fluctuations de l'environnement. Doctoral desertation, Université de Bretagne Occidentale, Brest.

Gutiérrez, J. L., Jones, C. G., Strayer, D. L., and Iribarne, O. O. (2003). Mollusks as ecosystem engineers: the role of shell production in aquatic habitats. Oikos 101, 79-90. doi: 10.1034/j.1600-0706.2003.12322.x

Hernández Fariñas, T., Ribeiro, L., Soudant, D., Belin, C., Bacher, C., Lampert, L., et al. (2017). Contribution of benthic microalgae to the temporal variation in phytoplankton assemblages in a macrotidal system. J. Phycol. 53, 1020-1034. doi: $10.1111 /$ jpy. 12564

Hubas, C., Sachidhanandam, C., Rybarczyk, H., Lubarsky, H., Rigaux, A., Moens, T., et al. (2010). Bacterivorous nematodes stimulate microbial growth and exopolymer production in marine sediment microcosms. Mar. Ecol. Progr. Ser. 419, 85-94. doi: 10.3354/meps08851

Jauffrais, T., Drouet, S., Turpin, V., Méléder, V., Jesus, B., Cognie, B., et al. (2015). Growth and biochemical composition of a microphytobenthic diatom (Entomoneis paludosa) exposed to shorebird (Calidris alpina) droppings. J. Exp. Mar. Biol. Ecol. 469, 83-92. doi: 10.1016/j.jembe.2015.04.014

Jesus, B., Brotas, V., Marani, M., and Paterson, D. M. (2005). Spatial dynamics of microphytobenthos determined by PAM fluorescence. Estuar. Coast. Shelf Sci. 65, 30-42. doi: 10.1016/j.ecss.2005.05.005

Jesus, B., Mouget, J.-L., and Perkins, R. G. (2008). Detection of diatoms xanthophyll cycle using spectral reflectance. J. Phycol. 44, 1349-1359. doi: 10.1111/j.15298817.2008.00583.x

Jesus, B., Rosa, P., Mouget, J.-L., Méléder, V., Launeau, P., and Barillé, L. (2014). Spectral-radiometric analysis of taxonomically mixed microphytobenthic biofilms. Remote Sens. Environ. 140, 196-205. doi: 10.1016/j.rse.2013.08.040

Jones, C. G., Gutiérrez, J. L., Byers, J. E., Crooks, J. A., Lambrinos, J. G., and Talley, T. S. (2010). A framework for understanding physical ecosystem engineering by organisms. Oikos 119, 1862-1869. doi: 10.1111/j.1600-0706.2010.18782.x

Juneau, P., Barnett, A., Méléder, V., Dupuy, C., and Lavaud, J. (2015). Combined effect of high light and high salinity on the regulation of photosynthesis in three diatom species belonging to the main growth forms of intertidal flat inhabiting microphytobenthos. J. Exp. Mar. Biol. Ecol. 463, 95-104. doi: 10.1016/j.jembe. 2014.11.003

Kristensen, E. (2000). "Organic matter diagenesis at the oxic/anoxic interface in coastal marine sediments, with emphasis on the role of burrowing animals," in Life at Interfaces and Under Extreme Conditions, eds G. Liebezeit, S. Dittmann, and I. Kröncke (Dordrecht: Springer), 1-24. doi: 10.1007/978-94-011-4148-2_1

Kühl, M., Lassen, C., and Jorgensen, B. (1994). Light penetration and light intensity in sandy marine sediments measured with irradiance and scalar irradiance fiber-optic microprobes. Mar. Ecol. Progr. Ser. 105, 139-148. doi: 10.3354/ meps105139

Laruelle, G., Regnier, P., Ragueneau, O., Kempa, M., Moriceau, B., Ni Longphuirt, S., et al. (2009). Benthic-pelagic coupling and the seasonal silica cycle in the Bay of Brest (France): new insights from a coupled physicalbiological model. Mar. Ecol. Progr. Ser. 385, 15-32. doi: 10.3354/meps07884

Lavergne, C., Beaugeard, L., Dupuy, C., Courties, C., and Agogué, H. (2014). An efficient and rapid method for the enumeration of heterotrophic prokaryotes in coastal sediments by flow cytometry. J. Microbiol. Methods 105, 31-38. doi: 10.1016/j.mimet.2014.07.002

Loomis, S. H., and van Nieuwenhuyze, W. (1985). Sediment correlates to density of Crepidula fornicata Linnaeus in the Pantanguanset river. Connecticut. Veliger $27,266-272$.

MacIntyre, H. L., Geider, R. J., and Miller, D. (1996). Microphytobenthos: the ecological role of the "secret garden" of unvegetated, shallow water marin habitats. I. Distribution, abundance and primary production. Estuaries 19, 186-201. doi: 10.2307/1352224

Manach, N. (1995). La biodéposition de la crépidule (Crepidula fornicata). Impact sur l'écosystème de la rade de Brest. Available at: http://archimer.ifremer.fr/doc/ 00014/12553/9419.pdf

Marques da Silva, J., Cruz, S., and Cartaxana, P. (2017). Inorganic carbon availability in benthic diatom communities: photosynthesis and migration. Philos. Trans. R. Soc. Lond. B Biol. Sci. 372:20160398. doi: 10.1098/rstb.2016. 0398

Martin, S., Thouzeau, G., Chauvaud, L., Jean, F., Guérin, L., and Clavier, J. (2006). Respiration, calcification, and excretion of the invasive slipper limpet, Crepidula fornicata L.: Implications for carbon, carbonate, and nitrogen fluxes in affected areas. Limnol. Oceanogr. 51, 1996-2007. doi: 10.4319/lo.2006.51.5.1996

Méléder, V., Launeau, P., Barillé, L., and Rincé, Y. (2003). Cartographie des peuplements du microphytobenthos par télédétection spatiale visibleinfrarouge dans un écosystème conchylicole. C. R. Biol. 326, 377-389. doi: 10.1016/S1631-0691(03)00125-2

Mermillod-Blondin, F., and Rosenberg, R. (2006). Ecosystem engineering: the impact of bioturbation on biogeochemical processes in marine and freshwater benthic habitats. Aquat. Sci. 68, 434-442. doi: 10.1007/s00027-006-0858-x

Moulin, F. Y., Guizien, K., Thouzeau, G., Chapalain, G., Mülleners, K., and Bourg, C. (2007). Impact of an invasive species, Crepidula fornicata, on the hydrodynamics and transport properties of the benthic boundary layer. Aquat. Living Resour. 20, 15-31. doi: 10.1051/alr:2007012

Newell, R., Fisher, T., Holyoke, R., and Cornwell, J. (2005). "Influence of eastern oysters on nitrogen and phosphorus regeneration in Chesapeake bay, USA," in The Comparative Roles of Suspension-Feeders in Ecosystems Earth and Environmental Sciences, eds R. F. Dame and S. Olenin (Dordrecht: Springer), 93-120.

Newell, R. I. E. (2004). Ecosystem influences of natural and cultivated populations of suspension-feeding bivalve molluscs: a review. J. Shellfish Res. 23, 51-61.

Ní Longphuirt, S., Clavier, J., Grall, J., Chauvaud, L., Le Loc'h, F., Le Berre, I., et al. (2007). Primary production and spatial distribution of subtidal microphytobenthos in a temperate coastal system, the bay of Brest, France. Estuar. Coast. Shelf Sci. 74, 367-380. doi: 10.1016/j.ecss.2007.04.025

Ní Longphuirt, S., Leynaert, A., Guarini, J.-M., Chauvaud, L., Claquin, P., Herlory, O., et al. (2006). Discovery of microphytobenthos migration in the subtidal zone. Mar. Ecol. Progr. Ser. 328, 143-154. doi: 10.3354/meps328143

Orvain, F., Galois, R., Barnard, C., Sylvestre, A., Blanchard, G., and Sauriau, P.G. (2003). Carbohydrate production in relation to microphytobenthic biofilm development: an integrated approach in a tidal mesocosm. Microb. Ecol. 45, 237-251. doi: 10.1007/s00248-002-2027-7

Paterson, D. M., Wiltshire, K. H., Miles, A., Blackburn, J., Davidson, I., Yates, M. G., et al. (1998). Microbiological mediation of spectral reflectance from intertidal 
cohesive sediments. Limnol. Oceanogr. 43, 1207-1221. doi: 10.4319/lo.1998.43. 6.1207

Perkins, R., Underwood, G., Brotas, V., Snow, G., Jesus, B., and Ribeiro, L. (2001). Responses of microphytobenthos to light: primary production and carbohydrate allocation over an emersion period. Mar. Ecol. Progr. Ser. 223, 101-112. doi: 10.3354/meps223101

Perkins, R. G., Williamson, C. J., Brodie, J., Barillé, L., Launeau, P., Lavaud, J., et al. (2016). Microspatial variability in community structure and photophysiology of calcified macroalgal microbiomes revealed by coupling of hyperspectral and high-resolution fluorescence imaging. Sci. Rep. 6:22343. doi: 10.1038/srep22343

Polerecky, L., Bissett, A., Al-Najjar, M., Faerber, P., Osmers, H., Suci, P. A., et al. (2009a). Modular spectral imaging system for discrimination of pigments in cells and microbial communities. Appl. Environ. Microbiol. 75, 758-771. doi: 10.1128/AEM.00819-08

Polerecky, L., Klatt, J. M., Al-Najjar, M., and de Beer, D. (2009b). "Hyper-spectral imaging of biofilm growth dynamics," in Proceedings of the 2009 First Workshop on Hyperspectral Image and Signal Processing: Evolution in Remote Sensing, (Grenoble: IEEE), 1-4. doi: 10.1109/WHISPERS.2009.5288974

Porter, E., Mason, R., and Sanford, L. (2013). Effects of shear stress and hard clams on seston, microphytobenthos, and nitrogen dynamics in mesocosms with tidal resuspension. Mar. Ecol. Progr. Ser. 479, 25-46. doi: 10.3354/meps 10206

Porter, E. T., Cornwell, J. C., and Sanford, L. P. (2004). Effect of oysters Crassostrea virginica and bottom shear velocity on benthic-pelagic coupling and estuarine water quality. Mar. Ecol. Progr. Ser. 271, 61-75. doi: 10.3354/meps271061

Powell-Jennings, C., and Callaway, R. (2018). The invasive, non-native slipper limpet Crepidula fornicata is poorly adapted to sediment burial. Mar. Pollut. Bull. 130, 95-104. doi: 10.1016/j.marpolbul.2018.03.006

Precht, E., Franke, U., Polerecky, L., and Huettel, M. (2004). Oxygen dynamics in permeable sediments with wave-driven pore water exchange. Limnol. Oceanogr. 49, 693-705. doi: 10.4319/lo.2004.49.3.0693

Prins, T. C., Smaal, A. C., and Dame, R. F. (1997). A review of the feedbacks between bivalve grazing and ecosystem processes. Aquat. Ecol. 31, 349-359. doi: 10.1023/A:1009924624259

R Core Team (2012). R: A Language and Environment for Statistical Computing. Available at: http://www.R-project.org/

Ramus, A. P., Silliman, B. R., Thomsen, M. S., and Long, Z. T. (2017). An invasive foundation species enhances multifunctionality in a coastal ecosystem. Proc. Natl. Acad. Sci. U.S.A. 114, 8580-8585. doi: 10.1073/pnas.1700353114

Riaux-Gobin, C., Llewellyn, C., and Klein, B. (1987). Microphytobenthos from two subtidal sediments from North Brittany. II. Variations of pigment compositions and concentrations determined by HPLC and conventional techniques. Mar. Ecol. Progr. Ser. 40, 275-283. doi: 10.3354/meps040275

Riera, P., and Richard, P. (1996). Isotopic determination of food sources of Crassostrea gigas along a trophic gradient in the estuarine bay of MarennesOléron. Estuar. Coast. Shelf Sci. 42, 347-360. doi: 10.1006/ecss.1996.0023

Rigolet, C., Thiébaut, E., and Dubois, S. (2014). Food web structures of subtidal benthic muddy habitats: evidence of microphytobenthos contribution supported by an engineer species. Mar. Ecol. Progr. Ser. 500, 25-41. doi: 10. 3354/meps10685

Romić, I., and Nakajima, Y. (2017). Ecosystem engineering as an energy transfer process: a simple agent-based model. Theor. Ecol. 11, 175-187. doi: 10.1007/ s12080-017-0357-9

Seuront, L., and Spilmont, N. (2002). Self-organized criticality in intertidal microphytobenthos patch patterns. Phys. A 313, 513-539. doi: 10.1016/S03784371(02)00989-5

Shumway, S. E., Ward, J. E., Heupel, E., Holohan, B. A., Heupel, J., Heupel, T., et al. (2014). Observations of feeding in the common Atlantic slippersnail Crepidula fornicata L., with special reference to the "mucus net.". J. Shellfish Res. 33, 279-291. doi: 10.2983/035.033.0127

Smith, D. J., and Underwood, G. J. C. (2001). The production of extracellular carbohydrates by estuarine benthic diatoms: the effects of growth phase and light and dark treatment. J. Phycol. 36, 321-333. doi: 10.1046/j.1529-8817.2000. 99148.x

Taylor, I. S., and Paterson, D. M. (1998). Microspatial variation in carbohydrate concentrations with depth in the upper millimetres of intertidal cohesive sediments. Estuar. Coast. Shelf Sci. 46, 359-370. doi: 10.1006/ecss.1997.0288

Underwood, G. J. C. (2005). Microalgal (Microphytobenthic) biofilm in shallow coastal waters: how important are species? Proc. Calif. Acad. Sci. 56, 162-169.

Underwood, G. J. C., and Paterson, D. M. (2003). The importance of extracellular carbohydrate production by marine epipelic diatoms. Adv. Bot. Res. 40, $183-$ 240. doi: 10.1016/S0065-2296(05)40005-1

van Broekhoven, W., Jansen, H., Verdegem, M., Struyf, E., Troost, K., Lindeboom, H., et al. (2015). Nutrient regeneration from feces and pseudofeces of mussel Mytilus edulis spat. Mar. Ecol. Progr. Ser. 534, 107-120. doi: 10.3354/ meps 11402

Woods, D. M. (1989). Paleoecology from Crepidula (Mollusca: Gastropoda) beds, James city formation (Pleistocene), North Carolina. Tulane Stud. Geol. Paleontol. 22, 69-91.

Wright, S. W., Jeffrey, S. W., Mantoura, R. F. C., Llewellyn, C. A., Bjornland, T., Repeta, D., et al. (1991). Improved HPLC method for the analysis of chlorophylls and carotenoids from marine phytoplankton. Mar. Ecol. Progr. Ser. 77, 183-196. doi: 10.3354/meps077183

Conflict of Interest Statement: The authors declare that the research was conducted in the absence of any commercial or financial relationships that could be construed as a potential conflict of interest.

Copyright (c) 2018 Androuin, Polerecky, Decottignies, Dubois, Dupuy, Hubas, Jesus, Le Gall, Marzloff and Carlier. This is an open-access article distributed under the terms of the Creative Commons Attribution License (CC BY). The use, distribution or reproduction in other forums is permitted, provided the original author(s) and the copyright owner(s) are credited and that the original publication in this journal is cited, in accordance with accepted academic practice. No use, distribution or reproduction is permitted which does not comply with these terms. 